\title{
Analysis of Available Nitrogen of Wheat Cultivated Soil Treated with Organic and Inorganic Source of Fertilizers
}

\author{
Shipa Rani Dey ${ }^{1}$ and Prasann Kumar ${ }^{1,2 *}$ \\ ${ }^{12}$ Department of Agronomy, School of Agriculture, Lovely Professional University, \\ Jalandhar, 144411, Punjab, India \\ ${ }^{2}$ Division of Research and Development, Lovely Professional University, Jalandhar, 144411, \\ Punjab, India
}

*Corresponding author

\section{A B S T R A C T}

Keywords

Crop, Dose, Effect, Fertilizer, HD2967, Nitrogen, Wheat

Article Info

Accepted:

22 July 2019

Available Online:

10 August 2019
The present study was carried out in Randomized Block Design with three replications and seven treatments with a variety of wheat HD2967 to identify the effect of organic and inorganic fertilizers under wheat cultivation. The result was recorded with the intervals of observation at 30 , 60 and 90 DAS. Application of Neem coated urea can increase the nitrogen content in wheat and availability of nitrogen was there, for a long period of time. The maximum significant effect was found in $\mathrm{T}_{3}$ with $443.76 \mathrm{~kg} \mathrm{ha}^{-1}$ and $440.51 \mathrm{~kg} \mathrm{ha}^{-1}$ at 60 and $90 \mathrm{DAS}$. The percentage increase in $\mathrm{T}_{3}$ was 82 and 81 at 60 and 90 DAS as compare to the other treatments.

\section{Introduction}

Wheat is a cereal crop that cultivated extensively throughout the world. It is Rabi seasonal crop and is widely grown in various climatic zones. Soil fertility is estimated by three major components such as nitrogen, phosphorus, and potassium ( $\mathrm{N}, \mathrm{P}$, and $\mathrm{K})$. Among these their essential nutrient nitrogen plays a major role to improve soil fertility. Even a slight deficiency of these nutrients will directly decline soil fertility level and as well as yield (Robertson et al., 2009). To improve the efficiency level of urea, it is coated with neem oil, to avoid the leaching losses and insect pest attack in field condition. Agronomical trial on Paddy and Wheat crops with Neem coated Urea as a source of Nitrogen has produced significantly higher yield at research and farm level. The use of Neem Coated Urea has been found to improve the uptake of N, P and K significantly. Since 2008, the Ministry of Chemicals and Fertilizers allowed Neem Coated Urea manufacturer to sell $\mathrm{NCU}$ at $5 \%$ above the MRP, to recover the cost of coating, however, cost of Neem kernel Oil and production as such of Neem Coated Urea has increased significantly. Neem oil is gotten by chilly squeezing neem seeds pursued by extraction 
with natural solvents (Nicoletti et al., 2012). The coating of urea was considered as one of the promising advances and is going about as productive slow release fertilizer. Beforehand, a ton of research work was done to test a number of covering materials, containing urease inhibitors and nitrification inhibitor, biodegradable polymers, and different polymers, yet surprising expense and powerful hazards limit their field applications. Though, right now just neem coated urea (NCU) is being made and used in the nation because of its low generation cost (Yang et al., 2012). The neem coated urea increment NUE by just $5-6 \%$ over urea in cereals even under best administration prepares (Singh et al., 2016). Utilization of neem cake mixed urea expanded the grain yield and nitrogen take-up. Neem cake covered urea expanded the percent nitrogen content. As the population is increasing day by day so, to minimize the hunger of the world need to improve wheat crop production (Spiertz, 2012). So, the application of organic and inorganic fertilizer is the best way to improve wheat production. Soil fertility is estimated by three major components such as nitrogen, phosphorus, and potassium ( $\mathrm{N}, \mathrm{P}$ and $\mathrm{K})$. Among these there essential nutrient nitrogen plays a major role to improve soil fertility. Even a slight deficiency of these nutrients will directly decline soil fertility level and as well as yield (Robertson et al., 2009).

\section{Materials and Methods}

The trial was led at the Agricultural research farmstead of Lovely Professional University, Phagwara. The farmstead is geographically arranged at 31 degrees 22 minutes and 31.81 seconds' north scope and 75 degrees and 23 minutes and 3.02 seconds' east longitude with an elevation of around 252 meters over the ocean level. The present investigation entitled "Available Nitrogen of Wheat Cultivated Soil Treated with Organic and Inorganic Source of
Fertilizers" was carried out of the year 20172018 at the Agricultural research farm, Lovely Professional University, Phagwara. The observation was done at 30,60, and 90 DAS. The observed parameter was soil available nitrogen $(\mathrm{N})$. The soil was collected from each plot of different treatments and replications.

\section{Analysis of Available Nitrogen (Subbiah and Asija 1956)}

In the test, the field was determined to utilize the technique which is present in the amount of available nitrogen.

\section{Reagent}

Potassium permanganate $\left(\mathrm{KMnO}_{4}\right)$

Boric acid

Mixed indicator

Sodium hydroxide $(\mathrm{NaOH})$

Sulphuric acid $\left(\mathrm{H}_{2} \mathrm{SO}_{4}\right)$

$\mathrm{N} \%=(\mathrm{S}-\mathrm{B}) * 0.0014 * 100 /$ weight of soil

$\mathrm{Kg} / \mathrm{ha}=\% * 22400$

Where,

$\mathrm{S}=$ Reading of sample

$\mathrm{B}=$ Reading or blank sample

A total of $20 \mathrm{~g}$ of soil sample was poured in Kjeldahl flask $(800 \mathrm{ml}) .1 \mathrm{ml}$ of liquid paraffin was added in $1 \mathrm{ml}$ of liquid paraffin.

Add total $100 \mathrm{ml}$ of $0.32 \%$ of $\mathrm{KMnO}_{4}$ and $2.5 \%$ of $\mathrm{NaOH}$ solutions simultaneously.

In Kjeldhal assemblage distillation of the solution was done. Collected ammonia in $250 \mathrm{ml}$ of Erlenmeyer flask which is having $25 \mathrm{ml}$ of the boric acid solution and then add a mixed indicator 2-3 drops.

The absorption of ammonia changed the colour of pink boric acid to green. 
Titration was done with $0.01 \mathrm{~N}_{2} \mathrm{SO}_{4}$ to the pink colour.

\section{Results and Discussion}

The soil available nitrogen at 30 DAS results in maximum significant effect in $\mathrm{T}_{3}$ with $436.4 \mathrm{~kg} \mathrm{ha}^{-1}$. The percentage increase in $\mathrm{T}_{3}$ was 80 at 30 DAS as compare to the other treatments. The lowest value was found in $\mathrm{T}_{1}$ with $286.33 \mathrm{k} \mathrm{kg} \mathrm{ha}^{-1}$ at $30 \mathrm{DAS}$. And the percentage increase in $T_{1}$ was 18 as compared to the control $\left(\mathrm{T}_{0}\right)$. The maximum significant effect was found in $\mathrm{T}_{3}$ with $443.76 \mathrm{~kg} \mathrm{ha}^{-1}$ and $440.51 \mathrm{~kg} \mathrm{ha}^{-1}$ at 60 and 90 DAS. The percentage increase in $T_{3}$ was 82 and 81 at 60 and 90 DAS as compare to the other treatments. The lowest soil available nitrogen was found in $\mathrm{T}_{5}$ with $308.45 \mathrm{~kg} \mathrm{ha}^{-1}$ and $307.42 \mathrm{~kg} \mathrm{ha}^{-1}$, respectively. The percentage increase in $\mathrm{T}_{5}$ was 26 for both dates as compare to the control $\left(\mathrm{T}_{0}\right)$.

Nitrogen is an element which is very much crucial for plant growth and reproduction. Nitrogen also helps in high biomass production. The application of nitrogen more than or less than the optimal level is not good for the plants. Soil available nitrogen is a part of nitrogen which can easily be absorbed by the plants (Table 1).The nitrogen has been reported in two major forms inorganic and organic (Dey et al., 2019a, b).

Minerals nitrogen is as the inorganic forms, whereas the organic matter is the form of organic matter and plant residues (www.grdc.com.au/Updates). It is reported that, 90 per cent nitrogen in the soil is organic in nature. Its availability is not easy to the plants [http://anz.ipni.net/]. Because, before its utilization, it must be converted into the soluble form of the compound like organic acid, amino acid and ammonia. These, conversion mediated through microorganism present in the soil. The parent material is plant residue and organic material. Nitrogen can be removed from organic matter and crops residue, decomposition, immobilization, solubilization and mineralization (www.grdc.com.au/Updates). Within the alkaline soil, urea always remain at the high risk to leach more and more within the soil around the dissolving granules. That why, the top dressing should be avoided in such type of soil (www.grdc.com.au/Updates). To avoid the ammonia volatilization the precision guidance to top-dress urea with direct delivery.

It is reported that, increasing legumes residues increases the soil organic matter through mineralization. The mineralization rate in summer and autumn may be high. This means that in the following crop, the rate of mineralization is the same or less than soil with no legume residues. Growers need to keep this in mind when budgeting fertilizer application rates (www.soilquality.org.au). Surface acidification can be achieved through the large amounts of soil mineral nitrogen at the time of sowing and leaching can be done beyond the root zone of coarse-textured soils (www.grdc.com.au/GCS96).

It is reported that, application of nitrogen in excess in early season can leads to the risk of haying of crops, if moisture are absent in the season. Agronomic practice results changes in soil organic matter, which leads to alteration in types of carbon and nitrogen present in the soil. It is the facts that, increase in the organic matter in the soil leads to more organic nitrogen in the soil available for the plants (www.grdc.com.au/GCS96). If the $\mathrm{C} / \mathrm{N}$ ratio is higher in the residue, than nitrogen immobilization will happen more and which leads to the reduced availability of nitrogen to the plants (Barman, 2019). Whereas, the low $\mathrm{C}$ : $\mathrm{N}$ ratio leads to higher mineralization of nitrogen and increases its availability to the plants (www.grdc.com.au/GCS97). 
Table.1 Soil available nitrogen in the treated soil

\begin{tabular}{|c|c|c|c|}
\hline Treatments & 30DAS & 60DAS & 90DAS \\
\hline T0 & $241.76^{\mathrm{g}} \pm 0.78$ & $243.53^{\mathrm{g}} \pm 0.29$ & $242.80^{\mathrm{g}} \pm 0.31$ \\
\hline T1 & $286.33^{\mathrm{f}} \pm 0.63$ & $287.91^{\mathrm{f}} \pm 0.08$ & $286.75^{\mathrm{f}} \pm 0.48$ \\
\hline T2 & $382.89^{\mathrm{b}} \pm 1.07$ & $386.82^{\mathrm{b}} \pm 0.93$ & $385.30^{\mathrm{b}} \pm 0.48$ \\
\hline T3 & $436.4^{\mathrm{a}} \pm 0.76$ & $443.76^{\mathrm{a}} \pm 0.81$ & $440.51^{\mathrm{a}} \pm 0.97$ \\
\hline T4 & $338.78^{\mathrm{d}} \pm 0.63$ & $341.98^{\mathrm{d}} \pm 0.06$ & $341.99^{\mathrm{d}} \pm 0.5$ \\
\hline T5 & $306.86^{\mathrm{e}} \pm 0.19$ & $308.45^{\mathrm{e}} \pm 0.31$ & $307.42^{\mathrm{e}} \pm 0.29$ \\
\hline T6 & $370.23^{\mathrm{c}} \pm 0.57$ & $374.06^{\mathrm{c}} \pm 0.47$ & $371.26^{\mathrm{c}} \pm 0.43$ \\
\hline
\end{tabular}

Where, DAS: Days after sowing. Data are in the form of Mean \pm SEM at $p<0.05$. The mean followed by different letters was significantly different at $\mathrm{p}<0.05$, according to DMRT for separation of Means. $\mathrm{T}_{0}=$ control; $\mathrm{T}_{1}=$ $100 \% \mathrm{RDF} ; \mathrm{T}_{2}=75 \% \mathrm{RDF}+25 \%$ Neem coated urea $\mathrm{T}_{3}=50 \% \mathrm{RDF}+50 \%$ Neem coated urea; $\mathrm{T}_{4}=75 \% \mathrm{RDF}+$ $25 \%$ vermicompost; $\mathrm{T}_{5}=50 \% \mathrm{RDF}+50 \%$ vermicompost; $\mathrm{T}_{6}=50 \% \mathrm{RDF}+25 \%$ Neem coated urea + $25 \%$ vermicompost.

Fig.1 Soil Available Nitrogen $\left(\mathrm{kg} \mathrm{ha}^{-1}\right)$

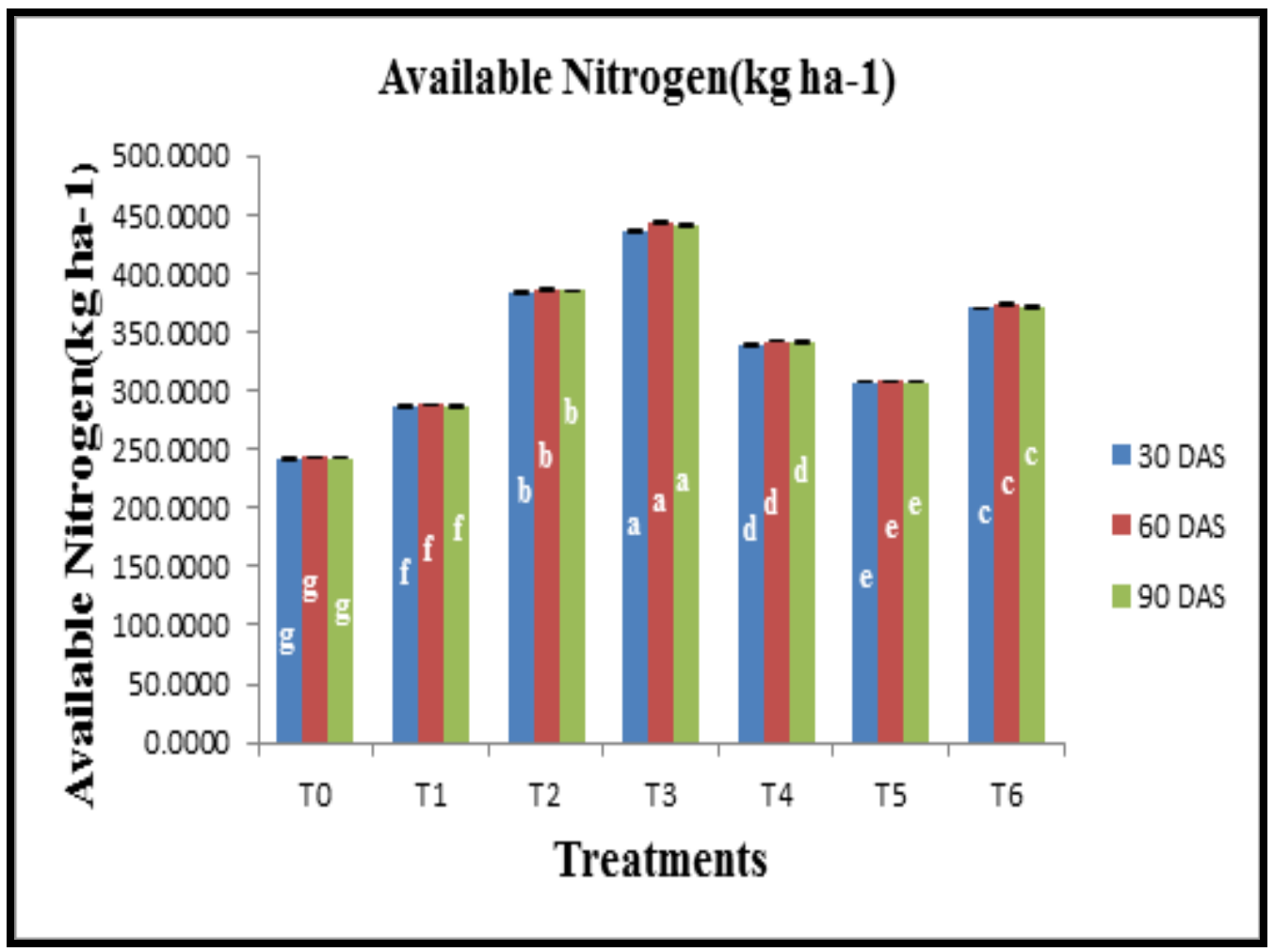

Where DAS: Days after sowing. Data are in the form of Mean \pm SEM at $\mathrm{p}<0.05$. The mean followed by different letters was significantly different at $\mathrm{p}<0.05$, according to DMRT for separation of Means. $\mathrm{T}_{0}=$ control; $\mathrm{T}_{1}=$ $100 \% \mathrm{RDF} ; \mathrm{T}_{2}=75 \% \mathrm{RDF}+25 \% \mathrm{Neem}$ coated urea; $\mathrm{T}_{3}=50 \% \mathrm{RDF}+50 \%$ Neem coated urea; $\mathrm{T}_{4}=75 \% \mathrm{RDF}+$ $25 \%$ vermicompost; $\mathrm{T}_{5}=50 \% \mathrm{RDF}+50 \%$ vermicompost; $\mathrm{T}_{6}=50 \% \mathrm{RDF}+25 \%$ Neem coated urea + $25 \%$ vermicompost. 
The soil available nitrogen at 30 DAS resulted from maximum significant effect in $\mathrm{T}_{2}$ with $449 \mathrm{~kg} \mathrm{ha}^{-1}$. The percentage increase in $\mathrm{T}_{2}$ was 85 at 30 DAS as compare to the other treatments. The lowest soil available nitrogen was found in $\mathrm{T}_{5}$ with $308.45 \mathrm{~kg} \mathrm{ha}^{-1}$ and $307.42 \mathrm{~kg} \mathrm{ha}^{-1}$, respectively. The percentage increase in $\mathrm{T}_{5}$ was 26for both dates as compare to the control $\left(\mathrm{T}_{0}\right)$.

\section{Acknowledgment}

Authors are thankful to Department of Agronomy, Lovely Professional University, Punjab.

\section{References}

Barman R., Dey SR and Kandpal G (2019). Effect of combined application of organic and inorganic fertilizers on growth attributes of wheat (Triticum $\begin{array}{lll}\text { aestivum } & \text { L.). Journal of }\end{array}$ Pharmacognosy and Phytochemistry, 8(3), 185-188.

Dey SR, Barman R and Kandpal G (2019a). Effect of combined application of organic and inorganic fertilizers on growth attributes of wheat (Triticum $\begin{array}{lll}\text { aestivum } & \text { L.). Journal of }\end{array}$ Pharmacognosy and Phytochemistry, 8(3), 576-578.

Dey SR, Kandapal G and Kumar P (2019b). Estimation of soil chemical parameters under the influence of organic and inorganic sources of nutrients under wheat cultivation. International Journal of Chemical Studies, 8(3), 576-578.

http://anz.pni.net
Nicoletti M, Petitto V, Gallo FR, Multari G, Federici E and Palazzino G. (2012). The modern analytical determination of botanicals and similar novel natural products by the HPTLC fingerprint approach. Stud. Nat. Prod. Chem. 37, 217-258.

Robertson G and Vitousek PM. (2009). Nitrogen in agriculture: balancing the cost of an essential resource. Annual review of environment and resources, 34, 97-125.

Singh B. (2016). Agronomic benefits of neem coated urea-a review. International fertilizer association review papers. Paris: International Fertilizer Association.

Spiertz, H. (2012). Avenues to meet food security. The role of agronomy on solving complexity in food production and resource use. European Journal of Agronomy, 43, 1-8.

Subbiah BV and Asija GL. (1956). A rapid procedure for determination of available nitrogen status in soil. Current Science, 25, 259-260.

www. grdc.com.am/uploads.

www. soilquality. org.an.

Yang Y, Zhang M, Li, Y, Fan X, and Geng, Y. (2012). Controlled Release Urea Improved Nitrogen Use Efficiency, Activities of Leaf Enzymes, and Rice Yield Nutrient Management \& Soil \& Plant Analysis extent of use and optimization of applications of CRU in cereal crops have been. Soil Science Society of America Journal. 76, 23072317.

\section{How to cite this article:}

Shipa Rani Dey and Prasann Kumar. 2019. Analysis of Available Nitrogen of Wheat Cultivated Soil Treated with Organic and Inorganic Source of Fertilizers. Int.J.Curr.Microbiol.App.Sci. 8(08): 2986-2990. doi: https://doi.org/10.20546/ijcmas.2019.808.345 